\title{
Conceptual Change Pedagogy and Its Effects On Students' Cognitive Achievement and Interest in Biology
}

\author{
Esther Etop Ekon, Nkoyo Bassey Edem \\ University of Calabar, Nigeria
}

\begin{abstract}
This study investigated the efficacy of conceptual change Pedagogy on students' cognitive achievement and interest in biology. Two research questions and two hypotheses guided the study. A non-equivalent, pretestpost-test quasi experimental design was employed. Four secondary schools were randomly selected in Calabar Municipality and Calabar south Local Government Areas, Cross River State. Two schools were randomly assigned to either experimental or control group. The experimental group students were exposed to the use of the conceptual change pedagogy while the control group students were exposed to the conventional instructional method. In each selected school, one intact arm of SSII class was randomly selected for participation as experimental or control group. Two hundred and seventy-two SSII biology students from the four secondary schools constituted the sample size. A sample note of lesson for effective teaching using conceptual change pedagogy was developed by the researchers. Two researcher-developed instruments named Biology Achievement Test (BAT) and Biology Interest Inventory (BII) were used for data collection. Their validity and their reliability indices were established using Cronbach alpha. Mean scores and standard deviation were used to answer the research questions while analysis of Covariance (ANCOVA) was used to test the null hypotheses. The result revealed that students taught biology using the conceptual change pedagogy outperformed that taught biology using conventional method. The students in the experimental group were more interested in the subject as compared to their counterparts in the control group because they were able to deal with their misconceptions about the concepts.
\end{abstract}

\section{Introduction}

The fast-growing accessibility and capability of today's educational development coupled with the global scientific scenario have given rise to the need for designing and implementing innovative teaching methods for effective teaching and learning of science subjects. At the moment, the West African Examination Council's Chief Examiners' yearly reports (2007-2012) [1] have shown a downward trend in the performance of students in science subjects especially biology. This poor performance has been attributed to many factors, one of which is the use of inappropriate teaching methods [2]. The method used presently to teach Biology in secondary schools otherwise known conventional or traditional method may not be so effective in the sense that it makes the learners to be passive listeners in the teaching/learning processes [3], [4]. The conventional method of instruction presents science learning as a mental process where facts are to be memorized, rather than a set of principles for application in the outside world. Onwuka cited in Ekon [5] added that teachers using the conventional method spoon-feed learners and so do not challenge them to discover new truths, new rules, and new methods of tackling problems as well as new values for themselves. The tendency therefore is for the learners to forget much of what is told them by the teachers. The conventional method lacks the capacity of stimulating students' interest in Biology because students' participation is reduced to the barest minimum. One of the aims of science education as stated in the National Policy on Education (NPE) is to inculcate in the learner, the spirit of inquiry and creativity through the exploration of the child's environment, Federal Republic of Nigeria [6]. The ability of the Biology student to explore his environment using the conventional method is reduced to minimum. Conventional teachers seem to regard time and so pay less attention to activities/practical aspects and as such the learners fall back to memorizing facts/concepts to pass examinations not necessarily to acquire science skills and knowledge. It neither helps majority of learners to be active participants in the teaching and learning processes nor allow the learners to develop appropriate science process skills [6] for better understanding, retention of concepts and application of scientific concepts in the outside world. The conventional method lacks the ability of dealing with students' Prior-conceptions brought into the classroom which may cause confusion in their rate of understanding science concept taught in the classroom. The implication of this is that learning may be difficult and uninteresting, and students see science subjects, especially biology as a difficult subject. Prior-conceptions may be as a result of incorrect thinking or flawed misunderstanding of a concept or a belief that is not based on correct information. On the other hand, it may a belief that is culturally based. Learners' prior conceptions usually cause conflict and interference during formal science teaching, Stofflet as cited in Ekon, [5]. In many 
cases, students develop partially correct ideas in order to solve problems in class while others fail to develop appropriate understanding of fundamental concepts from the beginning of their studies. There seem to be a conflict in understanding the learnt scientific concept which eventually interferes with understanding of the new concept learnt in the classroom. This may be another factor or rather a cankerworm causing students' poor performance in biology. From the afore-mentioned facts, conventional method neither creates a good interpersonal relationship nor allows the learners develop appropriate science process skills. It does not inculcate into the learner's creative abilities, improve their selfesteem and eliminate difficulties while learning as well as making them to be active participants in the classroom. Thus, the need to look out for better strategies for teaching and learning of science subjects especially biology. In recent times, several efforts are being made by researchers and policy makers toward designing better methodologies for effective teaching of science subject especially, biology. Among them is constructivism Iloputaife, [4]; Mandor, [3] and Ekon, [5]. Constructivism is an approach of instruction and learning involving interactive processes in social settings. It is problem solving oriented, allowing students to explore and work in groups. Bain [7] added that constructivism does not only allow learners work primarily in groups but that learning, and knowledge are interactive and dynamic. In addition, constructivism focuses and emphasizes on social and communicative skills, science process skills as well as collaboration and exchange of ideas and so has positive effects on the students' attitudes towards studying the science subjects like biology [5]. Constructivism is thus a strategy of learning based on the belief that knowledge is not a thing that can be simply given by the teacher in front of the classroom to learners seated at their desks. Rather, knowledge should be constructed by the learners through active mental developmental processes because learners are expected to be builders and creators of meaning of concepts and knowledge acquisition. Knowledge can only be created when learners are given the opportunity to be active in the class, exploring and manipulating learning materials and be able to make meaning of tasks. This means that learners must be responsible in creating knowledge. This is in line with Brunner's theory of learning which emphasizes that learning is an active process in which learners construct new ideas based on discovery or experience. This theory is relevant to this study in sense that, conceptual change model used in this study helps learners to discover meaning of concepts personally through the manipulation of the teaching materials provided by the teachers in the classroom. It is also in line with Vygotsky's theory of learning which states that social interaction influences cognitive development. Learners are not empty slates; they come into the classroom with ideas and beliefs. Therefore, priorconceptions and newly introduced scientific concepts are interwoven and influence each other as the child works out his own ideas quietly from the former idea and the newly introduced concept. This brings about perturbation/conflict that needs to be resolved in his/her mind. In other words, prior conceptions need be taken care of before introducing a new concept to the learner. Constructivist instructional models may be effective tools that could enable teachers provide learners with the opportunity to interact with them and even among themselves, in the classroom, in order to do away with prior-conceptions before the learning of new concepts. There are many constructivists' models, but this study uses the fivestep conceptual change instructional model (PEDDA) which involves five steps, where PEDDA is derived. The model, 'PEDDA' used is in this study stems from the five steps as illustrated in Figure 1.

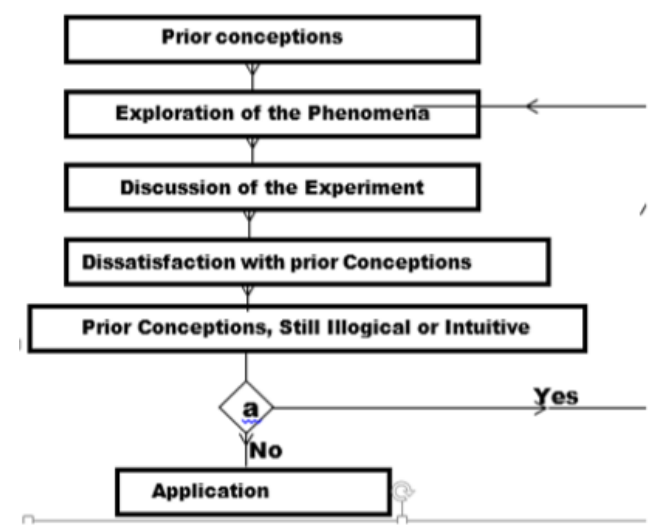

Key: a - Decision box

Figure 1. The Conceptual change Instructional Model (Source: Nworgu (1996) as adapted from Stofflet and Stoddart 1994.)

The steps involve in the Figure 1 are explained below:

Step 1: Identification of Prior-conception (P) where the teacher interacts with the students by asking them questions pertaining to the scientific concept to be taught, in order to identify any preconceived beliefs that will not help students to understand the scientific concept to be taught.

Step 2: Exploration of phenomena (E) where the teacher divides the students into homogenous groups and gives them materials to explore and manipulate with guided instructions.

Step 3: Discussion of experiment (D) where the students come together and discuss their 
observations and findings based on activities or experiments performed.

Step 4: Dissatisfaction with prior conception (D) where the teacher discovers through their discussions, questioning and answering techniques whether learners are still holding unto pre-conceived beliefs. If the learners are still holding unto the prior-conceptions that were brought into the classroom, the decision is 'Yes' and the teacher goes back to step II but if the decision is 'No', it means, the learners believe and accept the new concepts and reject their prior-conceptions. The teacher then proceeds to step 5 .

Step 5: Application (A) where learners can discuss concepts learnt confidently having facts and figures and are able to apply the knowledge outside the classroom setting. By that, knowledge is gained.

\section{A Sample note of lesson for teaching Osmosis using five-steps conceptual change instructional Model}

Date:

Class: SS2

Duration: 40 mins x 3

Topic: Cell and its environment

Subtopic: Osmosis Specific

Objectives: At the end of the lesson, the students should be able to:

(1) Define Osmosis correctly.

(2) Describe at least one experiment illustrating the process.

(3) List, at least two processes where the principle of osmosis can be applied.

Entry Behaviour: The students had known that molecules move faster in gases than in solids.

\section{Entry Behaviour Test}

(i) Define the term diffusion?

(ii) (ii) What makes perfume or insecticide to spread very fast once its spread in a room?

Instructional Materials: Blackboard, Drawings, basins or troughs, live herbaceous plant, Eosin solution, knife, salt, cold water, hot water, lima beans.

\section{Content Development:}

Step I: Identification of Prior Conception held by Students

The teacher interacts with the students by asking them questions like the following.

1. How does water enter into the leaves of pumpkin plant?
2. Why is salt or sugar solution given to dysentery or cholera patient or someone who is weak?

3. Is it because, living organisms drink water that is why, they are able to retain fluid in their cells? 4. Is it the retained fluid that comes out as sweat in human, how about plants?

\section{Step II: Exploration of the Phenomenon Activity} 1:

The teacher presents the materials for the experiments to the students. She or he groups the students homogenously and presents a plant (Herbaceous stem) dipped in coloured or Eosin solution to each group (see Figure 2a) and allows them to react on how the coloured solution can travel from the root to the leaves via the stem.

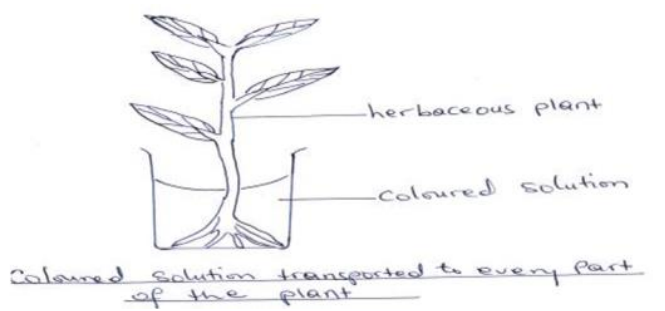

Figure 2a. Coloured solution transported to every part of the plant
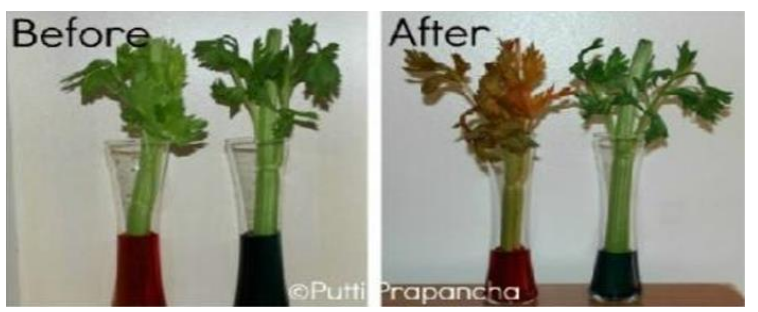

Figure 2b. Coloured solution transported to every part of the plant

Source: http://3.bp.blogspot.com/

The teacher allows them to discuss and agree among themselves.

\section{Instructions:}

1) After $2 \mathrm{hrs}$, take the plant out of the solution.

2) Cut parts of the plant using the razor blade provided

3) View cut surfaces under the microscope

4) Write down your observations for discussion

5) Is there any part of the cut surface stained?

6) What is the name of the stained part? 


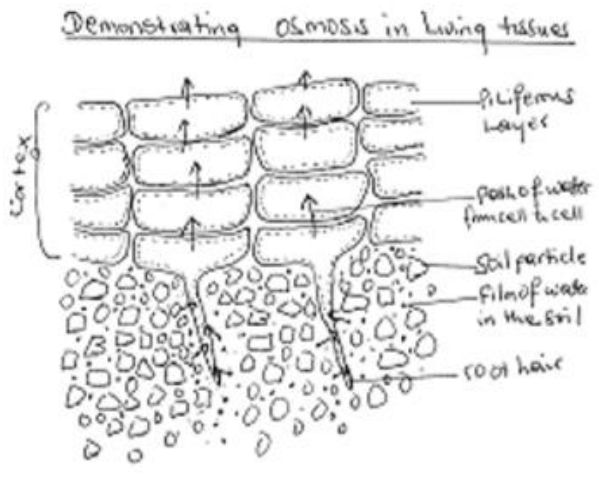

Figure 3. Diagram showing paths of water from the soil to the root

Activity 2: The students are given another experiment to perform as directed by the teacher using the lima beans to illustrate osmosis in living tissues. Instructions

(1) Put some quantities of common salt into a beaker (40ml), half fill it with tap water and stir till salt dissolves completely. Label it as beaker A

(2) Fill another beaker with tap water and label beaker $\mathrm{B}$

(3) Drop 2 lima bean seeds in each of the beakers

(4) Drop one lima bean seed on the table for comparison at the end of the experiment.

(5) Set the two beakers aside for about 15 minutes.

(6) Observe the three and

(7) Write out your observations.

\section{Step III: Discussion of the Experiment}

The students come together for general discussion on their activities. The teachers may ask the whole class this question: How does the stained solution get to the leaves? She or he guides them to bring out an appropriate definition of osmosis. She or he guides them into finding out the different types of permeability of some membrane and mentions examples of some them.

Example of non-living semi-permeable membrane includes: cellophane, parchment and risking tube. Example of living semi-permeable membrane includes: pig or sheep bladders, unripe paw-paw, Irish potato, yam tuber, cell membrane and tonoplast.

\section{Biological Significance of Osmosis}

(1) Processes in which osmosis is involved in plants a. Absorption of water from the soil by root hairs b. Movement of water/fluid from one living cell into another

c. Movement of water into and out of guard cells of stomata leading to opening and closing of the stomata.

d. Maintenance of turgor in plant cells
(2) Processes in which osmosis is involved in Animals

a. Re-absorption of water from glomerular filtrate in the kidney tubules (Excretion)

b. Absorption of water by the colon (large intestine) c. Movement of fluid/water from one living cell into another d. Maintenance of turgor in animal cells

e. Loss of water through sweating

\section{Step IV: Dissatisfaction with prior Conception}

After discussing with the use of illustrations and series of experiments, the teacher asks the following questions to see whether the students are satisfied with the scientific explanations. a) How does mineral salt in the soil get to the leaves of plants? b) Why are foodstuffs (fish or meat) preserved with salt or sugar? c) Why are leguminous foodstuffs soaked in water before cooking?

\section{Step V: Application}

If the students are satisfied with the scientific explanations and reject the prior conceptions, then the teacher should allow them answer the following questions to show their level of understanding:

- a) Mention two processes both in plants and animals where the principles of osmosis can be applied. b) Why doesn't honey ever spoilt? c) Why does a patient suffering from cholera given an infusion on reaching the hospital/clinic.

\section{Methodology}

The purpose of the Study was to explain the effective use of the conceptual change instructional model as a teaching strategy for better cognitive achievement and interest among biology students.

\section{Research Questions}

(1) What is the effect of conceptual change instructional model on students' cognitive achievement in biology?

(2) What is the effect of conceptual change instructional model on students' interest in biology?

\section{Hypotheses}

$\mathrm{H}_{01}$ : There is no significant difference in the mean scores of students' cognitive achievement when taught biology using conceptual change instructional model and those taught using the conventional method.

$\mathrm{H}_{02}$ : There is no significant difference in the mean scores of students' interest when taught biology 
using conceptual change instructional model and those taught using the conventional method.

\section{Research design}

The research design employed for the study was quasi-experimental approach as intact classes of not equivalent in terms of number in the class were used. The study areas were Calabar municipal council and Calabar south Local Government Areas in Cross River State. The population of the study comprised all the Senior Secondary Two (SS II) biology students in the twenty-two state-owned secondary schools in the study areas. A total of two hundred and seventy-two (272) SS2 biology students drawn from four schools formed a sample of the study. Two instruments: Biology Achievement Test (BAT) and Biology Interest Inventory (BII) were used for data collection.

The Biology Achievement Test (BAT) developed by the researchers was designed to measure students' achievement in biology. It was a 30-item multiple choice objective test and five theory questions focused on the Cell and its environment. The Biology Interest Inventory (BII) was designed to measure students' interest in biology. It consisted of 20 items where the students were required to put a tick $(\sqrt{ })$ in the appropriate box beside each statement. The two instruments were validated by experts and indices for reliability established as 0.785 for BAT and 0.787 for BII using Cronbach alpha.

\subsection{Method of data analysis}

Data collected were analyzed using mean scores and standard deviation to answer the research questions, while Analysis of Covariance (ANCOVA) was used in testing the hypotheses at 0.5 level of probability.

\section{Results}

Research Question One: What is the effect of the conceptual change instructional model on students' cognitive achievement in biology?

Table 1. Mean scores and standard deviation of students' cognitive achievement in biology

\begin{tabular}{lllllll}
\hline \multirow{2}{*}{ Groups } & \multirow{4}{l}{ Pre-test } & \multicolumn{2}{l}{ Post-test } & \multicolumn{2}{l}{ Mean } \\
\cline { 3 - 6 } & & $\bar{X}$ & SD & $\bar{X}$ & SD & Diff \\
\hline Experiment & 130 & 6.70 & 3.70 & 63.67 & 11.76 & 56.97 \\
Control & 138 & 7.31 & 4.06 & 30.67 & 9.19 & 23.36 \\
Total & 268 & 7.01 & 3.89 & 46.68 & 19.58 &
\end{tabular}

Key: Where ' $\mathrm{N}$ ' is the number of students involved in each case

The effect of the instructional model on students' cognitive achievement in biology is shown on Table 1 above. It shows that, the model had a more positive influence on the experimental group students in that they obtained a high mean achievement score of 63.67 compared to their counterparts in the control group who were taught using the conventional method with a mean achievement score of 30.67 . The efficacy of the instructional method was confirmed by the standard deviation where the experimental group had a standard deviation of 11.76 and the control group, 9.19. the high mean score of 63.67 with a moderate standard deviation of 11.76 obtained by the experimental group indicated that the objective of the instructional model was realized and a good mastery of the instructional unit (topic) was achieved and that enabled the students in the experimental group to perform better and had small difference in their inter-individual performance or scores. On the other hand, the control group had a low mean score of 30.67 with a standard deviation of 9.19 (higher than $1 / 5$ of the maximum possible mark). This indicated that mastery of the instructional topic was not achieved and their interindividual performance or scores were different.

Research Question Two: What is the effect of the conceptual change instructional model on students' interest in biology?

Table 2. Mean scores and standard deviation on students' interest in biology

\begin{tabular}{lllllll}
\hline Groups & \multicolumn{3}{l}{ Pre-test } & \multicolumn{2}{l}{ Post-test } & Mean \\
\cline { 3 - 6 } & $N$ & $\bar{X}$ & SD & $\bar{X}$ & SD & Difference \\
\hline Experimental & 132 & 18.07 & 4.65 & 63.57 & 7.46 & 45.50 \\
Control & 131 & 12.06 & 1.96 & 15.98 & 5.08 & 3.92 \\
Total & 263 & 15.08 & 4.67 & 39.86 & 24.68 & \\
\hline
\end{tabular}

Key: Where ' $\mathrm{N}$ ' is the number of students involved in each case

The effect of the instructional model on students' interest in biology is shown in table 2 above. The experimental group students who were taught using the conceptual change model were more interested in the subject, biology. They obtained a mean interest score of 63.57 and a standard deviation of 7.46 which is more than that obtained by those in the control group who were taught using the conventional method and had a mean interest score of 15.98. This result indicated that the instructional model has a positive impact in that it spurred the 
students' interest in the subject. The moderate standard deviation with a high mean interest scores of 63.57 indicated that the effect of the instructional model was realized compared to those in the control group who had a low mean interest score of 15.98 with a standard deviation of 5.08 (higher than $1 / 5$ of the maximum possible mark) which indicated a nonmastery of the instructional unit (topic). Since the standard deviation in the control group was higher than $1 / 5$ of the maximum possible marks, it means that there was a marked difference in their interindividual interest scores.

\section{Discussion and findings}

The effect of conceptual change instructional model on Biology students' cognitive achievement in Biology: The finding revealed that those taught with the conceptual change model in the experimental groups had a mean achievement score of 63.67 while those taught with the conventional method in the control groups had a mean achievement score of 30.67. This difference was further tested using a null hypothesis. The result from the hypothesis revealed that there is significant difference in the mean cognitive achievement scores of students taught biology using the five steps conceptual change instructional model as compared to those taught using the conventional method. This is a clear indication that the treatment using conceptual change model helped the students in the experimental groups to perform significantly better than their counterparts in the control group.

The significant enhancement of achievement of biology students' due to the conceptual change pedagogy may be as a result of its nature which is activity-oriented, student-centered and interactive. The students were able to construct or gained knowledge through exploring and manipulating the different activities they were engaged in. The active involvement of the students in the experimental class gave rise to more effective learning as was propounded by Jerome Brunner who encouraged learning by activity-discovery method, Also the teachers' knowledge of students' prior conception enhanced better teaching and learning processes hence the higher achievement scores in the experimental group.

The efficacy of conceptual change pedagogy in promoting learning and academic performance had long been demonstrated by many researchers like Iloputaife [4], Madu [8] and [5]. Iloputaife [4] who independently discovered that students taught with conceptual change instructional model, slightly outperformed those taught with conventional method also enhances better retention of learnt concepts.

Researches done outside Nigeria had confirmed these findings for instance, Duit [9] believed that constructivist-based instructional methods provided useful model for conceptual change and took into account the students' prior conception which yielded better results than conventional teaching approaches. Lord, Travis, Braudi \& King [10] revealed a significant difference between the constructivist class and the traditional class in favour of the constructivist class while comparing studentcentered and teacher centered instruction in college biology laboratories in India.

The constructivist group generally had higher scores than those taught using conventional method. It therefore means that, the constructivist model of instruction is efficient in redressing students' prior conception and creates room for better understanding of scientific concepts, thus influencing students' high achievement in science subjects especially biology. The finding of this study strengthens the assumption that any teaching strategy which is activity-based, student-centered yields better result than the conventional teaching method. Conceptual change pedagogy enables conceptual change among the learners and enhances better biology achievement.

The effects of conceptual change instructional model on students' interest in Biology The finding of the study in table 2 showed that the experimental group obtained a mean score of 63.57 while the control group obtained a mean score of 15.98. A null hypothesis was further used to explain this difference as it revealed that there is a significant difference in the mean interest score of students' taught biology using conceptual instructional model as compared to those taught with conventional method. This study revealed that the students taught biology using conceptual change instructional model were more interested in the lesson than those taught biology using the conventional method.

\section{Conclusion}

From the results obtained in the study, the researchers concluded that the conceptual change instructional model used in teaching biology is a better instructional strategy as the students taught with this model out-performed those taught with conventional method. The model facilitates interpersonal relationships while the students were active participants in the class while working in groups. This involvement helped deal with their priorconceptions thus, enhances better biology achievement and interest among the learners.

\section{Recommendations}

1) Teachers should adopt the conceptual change instructional model as a better instructional strategy but can also use any of the constructivist models of instruction. 2) The research indicated that learners come into the classroom with prior-conceptions which may distort the understanding of the new 
concepts. Teachers should endeavor to identify these prior-conceptions before introducing a new concept. 3) Teachers should make available instructional activities that will challenge the students to be actively involved in the classroom. The tasks should be the type that would develop their curiosity and interest in biology and not the complicated ones that would bring about frustration and boredom that may make them abandon the subject. 4) Teachers should give students opportunities to express themselves in variety of ways. 5) Curriculum planners should adopt constructivist approach to learning science subject especially biology, since the use of these models enhance better achievement in and outside the classroom setting.

\section{References}

[1] West African Examination Council, (2002-2007) Statistics of Performance. Research Division, Lagos.

[2] Edet, P.O., (1997). "Improving the Teaching and Learning Processes in Rural Areas." West African Journal of Educational Research, 3(1), pp. 96-101.

[3] Mandor. A. K., (2002). "Effects of Constructivistbased instructional models on Acquisition of Science Process Skill among junior secondary students". An Unpublished M.Ed. thesis. Nsukka: Faculty of Education, University of Nigeria.

[4] IIloputaife, E. C., (2000). "Effects of Analogy and conceptual change instructional models on Physics achievement of secondary school students. An unpublished Ph.D thesis. University of Nigeria. Nsukka.

[5] Ekon, E.E., (2013) "Effects of FiveStep Conceptual Change Instructional Model on Studens' Perception of their Psychosocial learning Environment, Cognitive Achievement and Interest in Biology". Unpublished Ph.D thesis, Faculty of Education, University of, Nigeria, Nsukka.

[6] Federal Republic of Nigeria, (2004). National Policy on Education. (4th ed). Lagos: Nigerian Educational Research and Development Council Press.

[7] Bain, J.O., (2004)." Constructivism in the Classroom" School Sciences Review, 61 (134), pp. 240-244.

[8] Duit, R., (1991). "On the role of analogies and metaphors in learning" science. Science Education, 75, pp.649-672.

[9] Madu, B.C., (2004). "Effects of constructivistbased Instructional Model on Students'
Conceptual Change and retention in Physics". An Unpublished Ph.D thesis. University of Nigeria, Nsukka.

[10] Lord, T., Travis, H; Brandi, $\mathrm{M}$ and King; L. (2008).“Comparing student-centered and teachercentered instruction in college Biology laboratory". trlord@lup.edu. Retrieved 4/16/2010. 